\title{
Description of Maritrema formicae sp. nov. (Digenea, Microphallidae) parasitic in the kelp gull, Larus dominicanus, from the Patagonian coast, Argentina
}

\author{
Julia I. Diaz ${ }^{*}$, Carmen Gilardoni ${ }^{2}$ and Florencia Cremonte ${ }^{2}$ \\ ${ }^{1}$ Centro de Estudios Parasitológicos y de Vectores (CCT La Plata, CONICET-UNLP), Calle 2 \# 584, 1900 La Plata, Argentina; \\ ${ }^{2}$ Centro Nacional Patagónico (CONICET), Boulevard Brown 2915, U9120ACD Puerto Madryn, Chubut, Argentina
}

\begin{abstract}
Maritrema formicae sp. nov. is described from the Patagonian coast, Argentina, based on adults obtained from the kelp gull, Larus dominicanus. The new species fits with the "eroliae complex" and can be distinguished from other related species mainly in shape and size of body, shape, size, and pattern of distribution of cirrus spines, uterus extension, number and size of eggs, vitellarium in a complete ring in all specimens, and its Neotropical distribution. The new species is sympatric with another species of the genus, Maritrema madrynense, which was recorded in the same host and locality.
\end{abstract}

\section{Keywords}

Trematode digeneans, Maritrema, Microphallidae, Larus, Patagonia, Argentina

\section{Introduction}

Species of Maritrema Nicoll, 1907 (Microphallidae) are parasites mainly of marine birds; gastropods act as first intermediate hosts, and crustaceans primarily as second intermediate hosts (Deblock 1971; Yamaguti 1971, 1975). Three species of the genus have been previously reported from Argentinean waters, i.e., Maritrema bonaerensis Etchegoin et Martorelli, 1997 from Larus atlanticus Olrog, Larus maculipennis Lichtenstein, and Larus dominicanus Lichtenstein; Maritrema orensensis Cremonte et Martorelli, 1998 from L. dominicanus and L. atlanticus; and Maritrema madrynensis Diaz et Cremonte, 2010 from L. dominicanus (Etchegoin and Martorelli 1997, Cremonte and Martorelli 1998, La Sala et al. 2009, Diaz and Cremonte 2010).

As Maritrema is a neuter name (article 30.1.2 of the International Code of Zoological Nomenclature; from Greek $\tau \rho \eta \dot{\mu} \mu$, neuter: a hole; type species: Maritrema gratiosum Nikoll, 1907), the original spelling bonaerensis, orensensis, madrynensis, misenensis, interrupta, patulus, minuta, jilenensis and kitanensis must be corrected to bonaerense, orensense, madrynense, misenense, interruptum, patulum, minutum, jilenense and kitanense for gender agreement (article 34.2).

During surveys of helminth communities in birds from the Argentinean Patagonian coast (Diaz and Cremonte 2010, Diaz et al. 2011), two Maritrema species were found parasitizing the intestine of the kelp gull, Larus dominicanus, M. madrynense and a new species which is described herein.

\section{Materials and methods}

Twenty nine kelp gulls, Larus dominicanus (Aves, Laridae), were collected from March 2000 to April 2004, in Peninsula Valdés and adjacent areas (24 adults from Fracasso Beach, $42^{\circ} 25^{\prime} \mathrm{S}, 64^{\circ} 07^{\prime} \mathrm{W}$, San José Gulf, and 5 adults from Puerto Madryn Beach, $42^{\circ} 47^{\prime} \mathrm{S}, 65^{\circ} 02^{\prime} \mathrm{W}$, Nuevo Gulf) of Chubut Province, Argentina. The birds were captured using a net, killed with ether, and transferred as soon as possible to the laboratory for dissection. The viscera were examined under a stereomicroscope. Adult digeneans belonging to the genus Maritrema were recovered from the intestine. The specimens were fixed in 5\% hot formalin, stored in $70 \%$ ethanol, stained with Semichon's acetocarmine, cleared in methyl salicylate, mounted in Canada balsam, and studied using a light microscope (LM).

Illustrations were made with the aid of a drawing tube. Dimensions of mounted specimens are given in micrometers with the mean value followed by the range in parentheses. The forebody was measured from the anterior extremity to the anterior margin of ventral sucker. Some fixed adult specimens were dehydrated, critical point dried, gold coated, and ob- 
served and photographed using a JEOL JSM 6360 LV (Jeol, Tokyo, Japan) scanning electron microscope (SEM).

\section{Description}

Maritrema formicae sp. nov. (Figs 1-6)

Diagnosis (measurements based on 14 stained specimens) (Figs 1-6): Body "pyriform" (i.e. pointed at anterior extremity and rounded posteriorly), 269 (230-350) long by 130 (102195) wide at ventral sucker level (Fig. 1). Spines transversally arranged covering entire body surface (Figs 3-5). Body spines multidentated, wider than longer (mean size 1.35 by 1.25 ), anterior spines compactly distributed (Figs 3-4). Oral sucker subterminal, $32(26-43)$ long by $32(26-40)$ wide. Ventral sucker 28 (23-40) long by $29(24-40)$ wide, located in the second third of body. Forebody 135 (115-187) long. Sucker ratio (ventral sucker/oral sucker width) 0.91 (0.82-1). Prepharynx 13 (6-20) long. Pharynx 20 (17-28) long by 15 (13-18) wide. Oesophagus 27 (20-35) long. Intestinal caeca reaching the middle of ventral sucker. Testes postovarian, lateral, symmetrical, oval, smooth or slightly lobed edges (Fig. 1). Right testis 36 (30-45) long axis by 29 (23-40) short axis, left testis $36(25-40)$ long axis by $29(25-35)$ short axis. Vasa differentia joining anterior region of seminal vesicle. Cirrus sac shaped as inverted "J", 102 (85-130) long by 23 (18-30) maximum width (Fig. 2); located between intestinal caeca and ventral sucker; with a very thin muscular wall. Cirrus sac enclosing oval seminal vesicle, 27 (20-45) long by 20 (17-25) wide; numerous prostatic cells surrounding a curled ejaculatory duct, and a spinous cirrus (Fig. 2). Invaginated cirrus 41 (33-55) long. Cirrus spines irregularly distributed, not covering entire cirrus, densely distributed at base. Proximal cirrus-spines are rose-thorn shaped and larger than distal ones (5.5-6.5 vs 3.0-4.0, respectively) (Figs 2, 6). Ovary submedian, postacetabular, oval, slightly lobed, partially displaced dextrally, covered by posterior border of ventral sucker obliquely disposed, 42 (30-52) long axis by 28 (23-35) wide (Fig. 2). Oviduct short. Seminal receptacle present. Ootype and Mehlis' gland situated immediately posterior to ventral sucker. Laurer's canal not observed. Metraterm with thin muscular diverticulated wall. Genital pore simple, slightly differentiated, unarmed, located at left side of ventral sucker. Uterus in hindbody, surrounding testes, from posterior border of cirrus sac to end of body. Operculated eggs from 31 to approximately 100 in number, 16 (14-18) long by 8.5 (8-9) wide (Fig. 1). Vitellarium with numerous small follicles forming 2 symmetrical ribbons, confluent posteriorly, enclosing uterus and testes (Fig. 1). Excretory vesicle "Y" shaped.
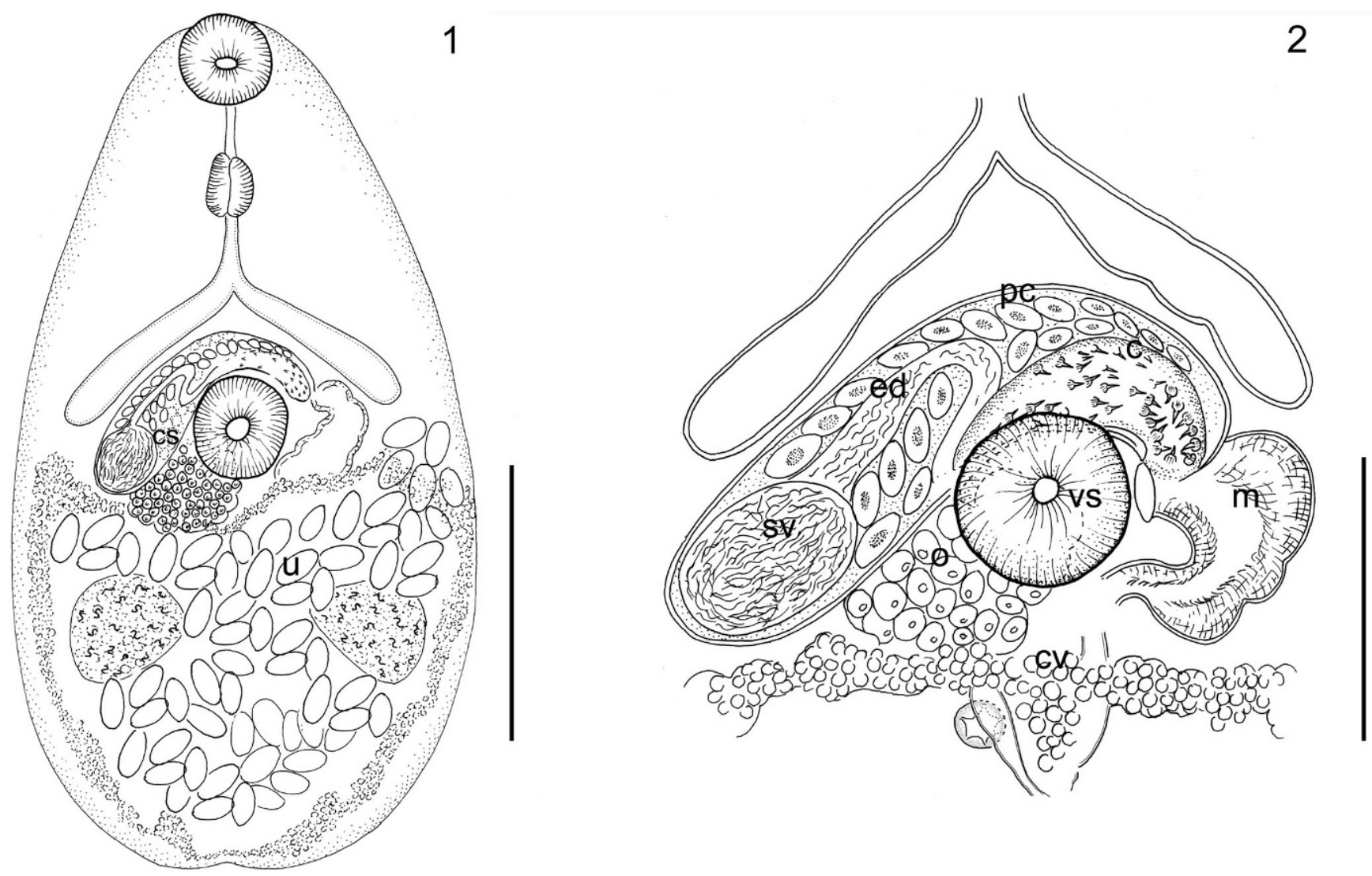

Figs 1 and 2. Maritrema formicae sp. nov. 1. Naturally obtained adult, ventral view. 2. Genital system, ventral view. Abbreviations: c, cirrus; cs, cirrus sac; cv, common vitelline duct; ed, ejaculatory duct; m, metraterm; o, ovary; pc, prostatic cells; sr, seminal receptacle; sv, seminal vesicle; u, uterus; vs, ventral sucker. Scale bars $=100 \mu \mathrm{m}(1), 50 \mu \mathrm{m}(2)$ 


\section{Taxonomic summary}

Type host: Larus dominicanus Lichtenstein (Aves, Laridae).

Type locality: Fracasso Beach $\left(42^{\circ} 25^{\prime}\right.$ S, $\left.64^{\circ} 07^{\prime} \mathrm{W}\right)$, Península Valdés, Chubut Province, Argentina.

Site of infection: Small intestine.

Prevalence: $17.3 \%$.

Specimens deposited: Holotype $\mathrm{N}^{\circ} 6501$ and paratypes $\mathrm{N}^{\circ} 6502$, voucher specimens $\mathrm{N}^{\circ} 6503$ at the Helminthological Collection of Museo de La Plata (CHMLP), Museo de La Plata, La Plata, and at the Parasitological Collection of the Centro Nacional Patagónico (CNP-Par N${ }^{\circ}$ ), Puerto Madryn, Argentina.

Etymology: The name of the new species is derived from the Latin for ant, "formica," as a tribute to "Hormiga", the nickname of our partner Miguel Angel Díaz (CENPAT-CONICET), indefatigable worker and lover of the sea. The species name is dedicated in his memory.

\section{Remarks}

The new species can be included in the genus Maritrema Nicoll, 1907 and in the subgenus M. (Maritrema) by the presence of postcaecal uterine coils, vitellarium in symmetrical ribbons surrounding uterine coils and testes, a cirrus pouch enclosing an invaginable cirrus like a finger of a glove turned inside out, a simple, superficial, and unarmed genital pore, and the absence of a spined acetabulo-atrial plate (Deblock 1971, 2008). The presence of a spinous cirrus enclosed in a cirrus sac places the new species closest to the "eroliae complex" proposed by Deblock and Canaris (1992), parasitizing mainly Charadriiformes. Within this complex are grouped several species, difficult to distinguish from each other, and very similar to M. eroliae Yamaguti, 1939. At present, twelve Maritrema species are included in the "eroliae complex". Deblock and Canaris (1992) grouped the species related to this complex into 3 subgroups according to body size, morphology of the vitellarium, and geographical distribution, i.e., group $\mathrm{A}=$ species smaller than $400 \mu \mathrm{m}$ and with horseshoe-shaped vitellarium; group $\mathrm{B}=$ species larger than $600 \mu \mathrm{m}$ and the vitellarium in a complete or subcomplete ring; and group $\mathrm{C}=$ some species with intermediate features between $\mathrm{A}$ and $\mathrm{B}$.

Following this grouping, and taking account that Maritrema formicae sp. nov. has a vitellarium in a complete ring but they are smaller than $600 \mu \mathrm{m}$, it should be located near to group $\mathrm{C}$, which is comprised of Maritrema misenense (Palombi, 1940), M. eroliae (sensu Deblock et Pearson, 1968), Maritrema interruptum Oshmarin, 1970, Maritrema papillorobusta Ke, 1976, and M. madrynense Diaz et Cremonte, 2010. In this group, only the smaller specimens of $M$. eroliae
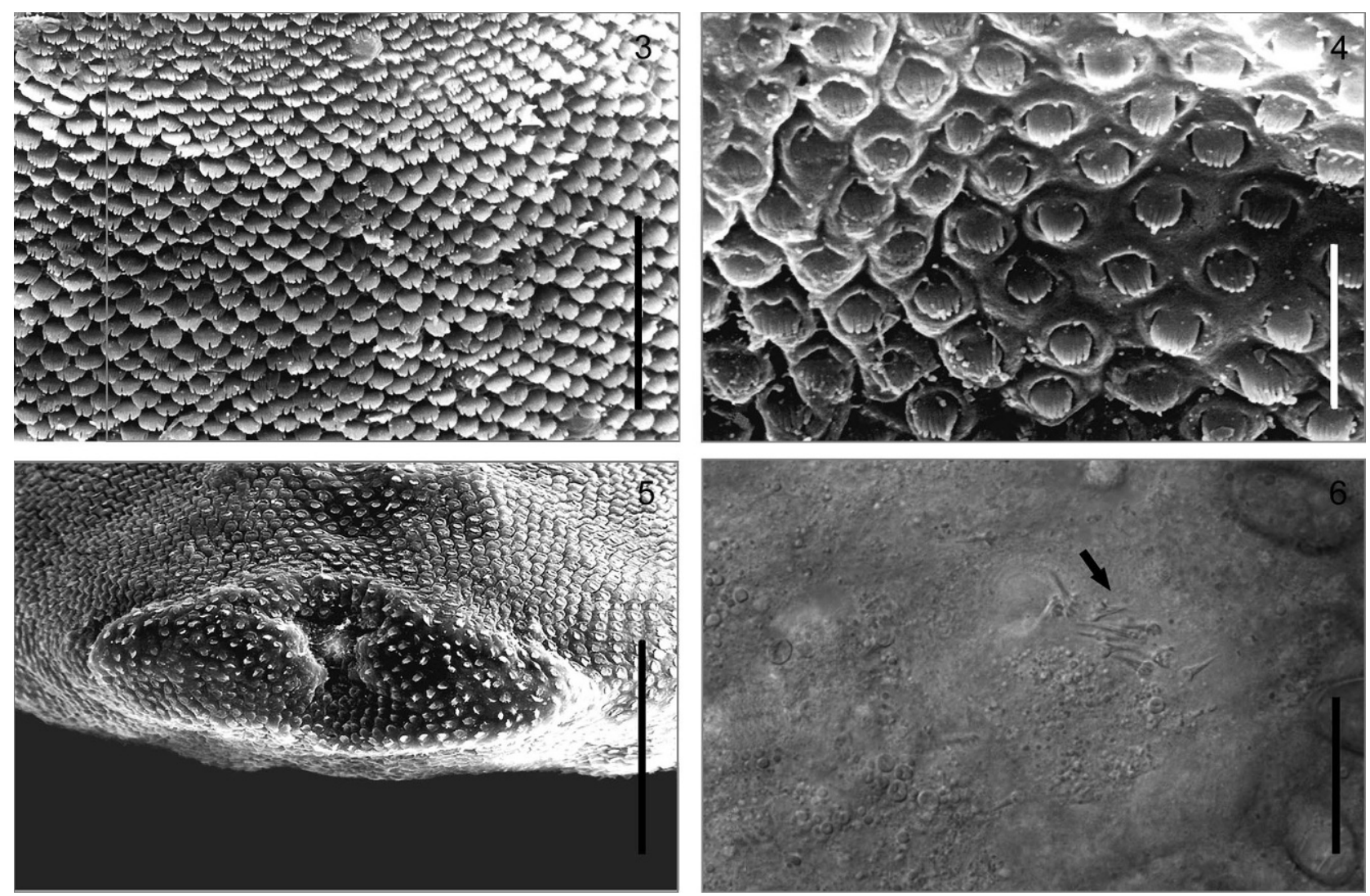

Figs 3-6. Maritrema formicae sp. nov. 3-5. Body spines (SEM). 3. Preacetabular dorsal spines. 4. Postacetabular dorsal spines. 5. Posterior spines, ventral view. 6. Details of cirrus spines (arrow) at LM. Scale bars $=10 \mu \mathrm{m}(3), 5 \mu \mathrm{m}(4), 30 \mu \mathrm{m}(5), 20 \mu \mathrm{m}(6)$ 
(sensu Deblock et Pearson, 1968) from Charadrius mongolus from Australia measure less than $400 \mu \mathrm{m}$ like the new species. However, the Australian specimens were restudied and identified later as to Maritrema spinosulum Deblock et Canaris, 1996, a species that was described as having a horseshoeshaped vitellarium, and the cirrus covered by a continuous lining of uniform small spines (Deblock and Canaris 1992, 1996). In contrast, M. misenense from Southern Europe, M. interruptum from Vietnam, M. papillorobusta from China, and M. madrynense from Argentina, measured more than $400 \mu \mathrm{m}$ in length. In addition, M. interruptum has a horseshoe-shaped vitellarium and $M$. papillorobusta has the cirrus totally covered by heterogeneous spines, and a horseshoe-shaped vitellarium. Also, the eggs of the new species are smaller than those from $M$. papillorobusta (14-18 vs 25-28) (Prévot et al. 1976; Deblock and Canaris 1992, 1996; Diaz and Cremonte 2010). Maritrema misenense possesses the cirrus partially covered by spines like M. formicae sp. nov. (Prévot et al. 1976). However, M. misenense, which was described based only on experimental adults, has a horseshoe-shaped vitellarium and the tip of cirrus is unarmed. Also, the new species has shorter spines (5-6 vs 11) and smaller eggs (14-18 vs 19-22 long; 89 vs 11-12.5 wide) than $M$. misenense.

On the other hand, taking into account the taxonomic difficulties arising from incomplete descriptions, poorly illustrated, and the lack of biological knowledge of species similar to $M$. eroliae, Deblock and Canaris (1992) also considered those species similar to $M$. eroliae in 5 groups of species which are likely to be similar each other, in order to simplify their study. Maritrema formicae sp. nov. is similar to some species into "Group I or patulus" and "Group II or eroliae". However, all species in Group I have a horseshoe-shaped vitellarium and, with the exception of Maritrema patulum Coil, 1955, were found only in the Palearctic or Indomalaya Regions. The new species has smaller eggs than Maritrema borneonse Fischthal et Kuns, 1973 (14-18 vs 25-28). Moreover, in some of the species included in these two groups, the precise morphology, size or distribution of the cirrus spines were not described (i.e., Maritrema minutum Ke, 1976; Maritrema jilenense Zhong, Ke-Feng et Min-Zen, 1988; Maritrema eroliae sensu Ogata, 1951) (Deblock and Canaris 1992, 1996). Maritrema kitanense Shibue, 1953 and Maritrema magnicirrus Belopolskaia, 1952 were proposed as synonymies and/or declared invalid (Deblock 1975), and other species where restudied and found to have a smooth cirrus (i.e., M. patulum) (Deblock and Canaris 1996). Other species including in these groups I and II were considered and compared above (i.e., $M$. misenense, $M$. interruptum and $M$. papillorobusta).

Considering the valid species with a spinous cirrus and vitellarium in a complete ring, only $M$. madrynense has a Neotropical distribution (Diaz and Cremonte 2010). Maritrema formicae sp. nov. differs from $M$. madrynense in body shape (pyriform vs linguiform), size (230-350 long by 102195 wide vs 400-690 long by 235-390 wide), cirrus size (3355 vs 100-150), patterns of distribution of cirrus spines (partially vs totally covered), number of eggs (less to $\sim 100 \mathrm{vs}$ more than four hundred), and egg size (14-18 long by 8-9 in wide vs 18-23 long by 10-12). Size and shape of body spines in the new species differ from those of M. madrynense; in $M$. formicae sp. nov. they are smaller than in M. madrynense (average of dorsal body spines: 1.35 by 1.25 vs 2.74 by 4.52 ). Maritrema formicae sp. nov. and M. madrynense occur sympatrically in the same host species; however, differences between them are clear.

\section{Discussion}

Many species of Maritrema have been reported parasitizing avian hosts around the world (see Diaz and Cremonte 2010 and references therein). In contrast, only a few species have been reported in South American birds: Maritrema nicolli Travassos, 1920; Maritrema bravoae Caballero et Ibáñez, 1970; Maritrema magdalenae Werding, 1973; M. bonaerense Etchegoin et Martorelli, 1997; M. orensense and M. madrynense (see Deblock 1971; Caballero and Ibáñez 1970; Etchegoin and Martorelli 1997; Cremonte and Martorelli 1998; Diaz and Cremonte 2010). Maritrema spp. reported parasitizing birds of the genus Larus in Argentina are M. bonaerense, M. orensense and M. madrynense (Lunaschi et al. 2007, Diaz and Cremonte 2010, Diaz et al. 2011). Only M. madrynense fits with the "eroliae complex". Adults of this last species parasitized L. dominicanus and the metacercaria was found in the crab Cyrtograpsus altimanus Rathburn (Grapsidae) at the same locality as the new species (Diaz and Cremonte 2010, Diaz et al. 2011). Recently, Gilardoni et al. (2011) described larval stages of two different Maritrema species (i.e., Maritrema sp. 1 and Maritrema sp. 2) in a survey of larval digeneans in the intertidal snails from the northern Patagonian coast. Gilardoni et al. (2011) suggest that sporocysts and cercariae of Maritrema sp. 2 from the gastropod Siphonaria lessoni (Blainville) probably correspond to M. madrynense. Taking into account that only 2 adult Maritrema species (i.e., M. madrynense and M. formicae sp. nov.) were found in the study area, and also two different species were identified as larval stages in the same area, it is probable that Maritrema sp. 1 registered by Gilardoni et al. (2011) from Crepipatella dilatata Lamarck, corresponds to M. formicae sp. nov. Experimental and/or molecular analyses are needed to test these suggestions.

As was mentioned by Deblock and Canaris $(1992,1996)$ and Diaz and Cremonte (2010) there are doubts regarding the correct identification of specimens reported as M. eroliae by Yamaguti (1939) and subsequent authors, as well as other related species, as a result of incomplete descriptions, non or poorly illustrated specimens, and lack of knowledge about the biology of the species. Additionally, there are many descriptions and/or reports of metacercariae or immature specimens. Maritrema formicae sp. nov. can be distinguished from other species using a combination of features including size, shape of vitellarium, size and pattern of distribution of 
cirrus spines, number and size of eggs, and geographical distribution.

Acknowledgements. The authors gratefully thank Miguel Angel Díaz and Ulyses Pardiñas for helping us in collecting the hosts, Maria Cristina Estivariz for the drawings, and the staff of the Servicio de Microscopía Electrónica de Barrido of the Museo de La Plata. We specially thank Dr. Nestor Cazzaniga for his valuable collaboration in the taxonomical review of Maritrema species and Dr. Mike Kinsella for the critical reading of the manuscript. Fieldwork was conducted in a Protected Natural Area of Chubut Province with permits from the Secretaría de Turismo y Áreas Protegidas. This study was supported by ANPCyT (PICT 01374), UNLP (N 628) and PIP CONICET to F. Cremonte. Authors are members of CONICET.

\section{References}

Caballero C.E., Ibáñez H.N. 1970. Estudios helmintológicos de la República de Perú. I. Dos especies de Trematoda de la familia Microphallidae Travassos, 1920 que parasitan Aves. Annales del Instituto de Biologia de la Universidad Nacional Autónoma de Mexico, Serie Zoologie, 41, 29-38.

Cremonte F., Martorelli S.R. 1998. Description of a new species of Maritrema (Digenea: Microphallidae) from Larus dominicanus (Aves: Laridae) in Buenos Aires coast, Argentina. Folia Parasitologica, 45, 230-232.

Deblock S. 1971. Contribution à l'étude des Microphallidae Travassos, 1920. XXIV. Tentative de phylogénie et de taxonomic. Bulletin du Museum Naturelle d'Histoire Naturelle, 3ème Serie, Zoologie, 7, 353-468.

Deblock S. 1975. Contribution à l'étude des Microphallidae Travassos, 1920 (Trematoda) XXX. A propos d'espèces décrites au Japon par S. Yamaguti C. - Maritrema eroliae et le genre Pseudospelotrema. Annales de Parasitologie Humaine et Comparée, 50, 45- 54.

Deblock S. 2008. Family Microphallidae Ward, 1901. In: (Eds. R.A. Bray, D.I. Gibson and A. Jones) Keys to the Trematoda. Vol. 3. CABI Publishing, Wallingford, U.K., 451-495.

Deblock S., Canaris A.G. 1992. Contribution à l'étude des Microphallidae Travassos, 1920 (Trematoda). XLIII- De six espèces
d'Afrique du sud dont une d'un genere nouveau. Annales de Parasitologie Humaine et Comparée, 67, 204-218.

Deblock S., Canaris A.G. 1996. Microphallidae, Trematoda: XLVIII. Quatre Maritrema du grupe Eroliae parasites d'Oiseaux australiens. Parasite, 4, 357-361.

Diaz J.I., Cremonte F. 2010. Development from metacercaria to adult of a new species of Maritrema (Digenea: Microphallidae) parasitic in Kelp Gull, Larus dominicanus, from Patagonian coast, Argentina. Journal of Parasitology, 96, 740-745. DOI: 10.1645/GE-2343.1.

Diaz J.I., Cremonte F., Navone G.T. 2011. Helminths of the Kelp Gull, Larus dominicanus, from the northern coast of Patagonia and their relationships with diet and behaviour of the host. Parasitology Research, 109, 1555-1563. DOI:10.1007/s004 36-011-2396-2.

Etchegoin J.A., Martorelli S.R. 1997. Description of a new species of Maritrema (Digenea: Microphallidae) from Mar Chiquita coastal lagoon (Buenos Aires, Argentina) with notes on its life cycle. Journal of Parasitology, 83, 709-713. DOI: 10.2307/ 3284251

Gilardoni C., Etchegoin J.A., Diaz J.I., Iturate C., Cremonte F. 2011. A survey of larval digeneans in the commonest intertidal snails from northern Patagonian coast, Argentina. Acta Parasitologica, 56, 163-179. DOI: 10.2478/s11686-011-0021-2.

La Sala L., Martorelli S.R., Alda P., Marcotegui P. 2009. Some digeneans from Olrog's Gull Larus atlanticus Olrog, 1958 (Aves: Laridae) from the Bahía Blanca Estuary, Argentina. Comparative Parasitology, 76, 113-116. DOI: 10.1654/4389.1.

Lunaschi L.I., Cremonte F., Drago F.B. 2007. Checklist of digenean parasites of birds from Argentina. Zootaxa, 1403, 1-36.

Prévot G., Bartoli P., Deblock S. 1976. Cycle biologique de Maritrema misenensis (A. Palombi, 1940) n. comb. (Trematoda Microphallidae Travassos, 1920) du midi de la France. Annales de Parasitologie Humaine et Comparée, 51, 433-446.

Yamaguti S. 1939. Studies on the helminth fauna of Japan. Part 25. Trematodes of birds. IV. Japanese Journal of Zoology, 8, 129210 .

Yamaguti S. 1971. Synopsis of digenetic trematodes of vertebrates. 1st Ed. Keigaku Publishing Co., Tokyo, Japan, 1074 pp.

Yamaguti S. 1975. A synoptical review of the life history of digenetic trematodes of vertebrates, with a special reference to the morphology of their larval forms. Keigaku Publishing Co., Tokyo, Japan, 590 pp.

(Accepted February 23, 2012) 